\title{
Integrated Management of Fungal Diseases in Potato
}

\author{
Arshdeep Singh and Jagjeewan Singh* \\ College of Agriculture, Punjab Agricultural University, Ludhiana, India \\ *Corresponding author
}

\begin{tabular}{|l|}
\hline Ke y w o r d s \\
$\begin{array}{l}\text { Potato, Integrated } \\
\text { disease } \\
\text { management, Bio- } \\
\text { control }\end{array}$ \\
\hline Article Info \\
\hline $\begin{array}{l}\text { Accepted: } \\
\text { 26 July 2018 } \\
\text { Available Online: } \\
\text { 10 August } 2018\end{array}$ \\
\hline
\end{tabular}

A B S T R A C T

Among major food crops, potato occupies fourth position following rice, wheat and maize across the globe. There are several factors affecting the crop yield and quality in potato of which disease is one of the most important factors. Potato diseases are caused by fungi resulting in the immense economic loss, posing the threat to food security and sustainable agriculture. Therefore, effective disease management is essential to overcome these risks. In this review, the objective is to discuss the disease causing pathogen, symptoms, factors favouring disease and integrated management of early blight, late blight, black scurf and wart diseases. The famous Irish famine disease i.e. late blight is a major challenge in potato, which can be controlled with the help of intercropping. In addition to late blight, other major complex diseases mentioned above can cause significant potato yield loss. Pathogen survival in soil prohibits the sustainable potato production in same field. However, as new strain develops, no management practice is effective when used alone. Therefore, integrated disease management approach i.e. chemical control in combination with bio-control agents, is the most efficient, cost effective and eco-friendly way to effectively combat pathogens. For complex diseases, the common control measures employed worldwide include the use of tolerant cultivars, crop rotation and other practices; singly or collectively have met limited success. Therefore, there is a dire need of extending research for disease management in potato for better food quality.

\section{Introduction}

Potato (Solanum tuberosum L.) ranks fourth following wheat, rice and maize worldwide. Population growth in this world possesses a serious concern with regard to natural resources i.e. land, air and water. Following this, potato holds guarantee aimed at nourishment to a great many individuals particularly in developing nations. Maximum capacity of the yield can be acknowledged just if pests and diseases are monitored.
Potato yield can be influenced by roughly 160 diseases and disorders of which 50, 10 and 40 are caused by fungi, bacterial and viral infections, respectively and others by nonparasitic, or because of obscure causes. These may influence potato at any phase of harvest development or not withstanding amid capacity. They may influence foliage, tubers or both. Condition favouring pathogens can demolish the harvest. The aftermaths of verifiable potato starvation in Europe especially in Ireland caused by late blight 
have been all around recorded (WoodhamSmith, 1962). Tuber illnesses like scab, black scurf may not wreck the harvest but rather can incredibly decrease quality and market value of the product. With the introduction of resistant cultivars and enhanced cultural practices, the disease infection situation may change now and again which require periodic observation. Diseases may likewise be influenced by any environmental change such as global warming (Kankoranta, 1996. The present review focuses up-to-date information on improvements that have occurred worldwide. Information is arranged under the following headings: symptoms, pathogen, epidemiology and control for each of important fungal diseases. This might be utilized as a part of better administration of the harvest and enhancement in food quality. Some important diseases causes by fungus with regard to food quality are considered under, for the effective management strategies.

\section{Early blight}

Alternaria solani requires free water in order to germinate on leaf surface referring to high humidity requirement. The ideal temperature for its growth is $26.6-29.4{ }^{\circ} \mathrm{C}$.

Symptoms: Ellis and Martin (1882) firstly described the disease symptoms. Older leaves are affected primarily (Jones, 1893). Black lesions encircled by concentric rings on leaves, creating 'target spot' effect are the key symptoms contrary to greenhouse-inoculated plants, due to difference in moisture, temperature etc. (Waals et al., 2001). The pathogen enlarges lesions surrounded by a narrow chlorotic halo, which further moves to uninfected epidermal cells and eventually cause death of the leaf, stem or petiole (Rands, 1917). Tuber infection illustrated via rotting of tubers, sunken surface lesions.
Control: Cultural practices can effectively control early blight, such as crop rotation for 3-5 years using the site selection methodology, non-preferable host crop plants, nourishing crops, sanitation of fields, escaping prevailing water stress or popularly known as drought conditions and using disease-free seed tubers for sowing (Madden et al., 1978). Usually, grain and fodder crops, like maize (Zea mays L.) are best for rotation, including maize (Zea mays L.). Large area under potato or tomato or both, results in favour of occurrence of disease (Shtienberg and Fry, 1990). Planting early blight tolerant cultivars may also help in minimizing the pathogen attack. However, Shtienberg and Fry (1990) demonstrated that effect of early blight is not associated with host resistance. Before harvesting maturation of tubers reduces tuber infection, escapingextreme wounding during or afterthe potato tuber harvesting, especially while storage (Waals et al., 2001). However, spraying protectant fungicide on vine during early days of the growing season is a good chemical control (Jones, 1912; Douglas and Groskopp, 1974). Also, plots treated with contact fungicides yielded 20-40 \% more than in untreated plots on experimenting in Colorado (Harrison and Venette, 1970), whereas chemical control of early blight with captafol, triphenyltin hydroxide resulted in approximately $90 \%$ yield increase in Minnesota on comparing it with the unsprayed controls of the treatmentsin the conducted experiment by Teng and Bissonnette (1985). Applications of fungicides at appropriate decreases number of sprays and also help sustaining the tuber yield and quality. Additionally, covering the entire foliage via aerial fungicidal application to prevent disease spreading is of utmost importance. Therefore, combination of practices, that is, crop rotations, chemical application and good storage facilities ably manage the prevailing threat from early blight occurrence. 


\section{Late blight}

The development of fungus Phytophthora infestans famous for Irish famine occurs at $16-24^{\circ} \mathrm{C}$ (Vowinekel, 1925) and 90-100\% relative humidity. Younger plants are more susceptible (Lowings and Acha, 1959), whereas water stress increases resistance in potato crop (Carnegie and Colhoun, 1980).

Symptoms: Water-soaked irregular pale green lesions appearedcommonlycloseto the leaves tip and margins, resulting in necrotic spots. A white mildew, comprisingof pathogen sporangia and spores, appears on infected leaves lower surface especially around the necrotic lesions' edges. Infected parts of the potato crop frail and may end up.Crop is destroyed in week after blackish appearance occurs.During storage, rotting of the infected tubers occur.

Management: Soil remediation and roughing (Flier and Turkensteen, 1999) should be done for reducing the disease epidemic. Also, infected plants on dumps, as experiments conducted under the stewardship of Zwankhuizen et al., (2000), covered with black plastic sheet (Cooke et al., 2011) provides relief from infection. Crop rotation, early-maturing cultivars, early planting, Avoiding excess nitrogen, use of systemic fungicides during the early days of the season can be useful to succeeding managing the seed infected late blight occurrence. Roy et al., (2001) revealed that higher phosphorus and potassium doses give the greater potato tuber yield during severely pathogen attacked crop year. Crop rotations for three or more years are most effective in the gap of potato growing crop years as demonstrated by the Hannukkala et al., (2007) and also independently by the another scientist Bodker et al., (2006). For tuber infection reduction, ridge sowing, maximum number of hoeings, proper maturity harvesting time and avoiding long potato harvest products transportation is recommended (Arora et al., 2014). However, resistant cultivars development using Solanum demissum (Niederhauser et al., 1996) and screening methodology has played significantly the finest role towards disease management (Tiwari et al., 2013).Fungicidal application reduces as foliage and tubers resist to late blight. Mixing and growing susceptible and resistant cultivars yield better than grown solo (Garrett and Mundt, 2000). Application of boron concentration with reduced fungicide propineb + iprovalicarbrate was significantly effective than fungicide alone treated plants (Frenkel et al., 2010).

Late blight can also be suppressed by phosphorus acid spray (Tsai et al., 2009). Substantial reliance towards fungicides poses dangerfor the entire biodiversity (Bradshaw $e t$ al., 2000). In addition, Biocontrol agents (BCAs) and biopesticides might upsurge as protected alternative for utilization of synthetic fungicides. Threat to late blight pathogen by some naturally occurring microorganisms such as Pythium ultimum (Kuzuetsova et al., 1995), Penicillium aurantiogriseum (Roy et al., 2001), Trichoderma spp., Pseudomonas syringae and Fusarium graminearum (Gupta et al., 2004) etc. positively significant tested under various scientists and various studies. Also in organic production, Bounes and Finckh (2008) stated, strip cropping fundamentally diminished late blight severity in potato, when the harvest was planted opposite to the wind along with the grass clover. Also, potato is garden crop in Ethiopia's central highland and intercropping with brassica at a lower population being an ordinary practice but crop like garlic is also grown as a sole crop in the same garden. Of the different alternatives accessible in the zenith, cropping systems, other than such a large number of advantages identified with intercropping, disease problem is low in an intercropping generation systems 
than traditional one (Rajputt et al., 2017). In Ethiopia, the research for evaluating intercropping effect on potato yield against late blight. The result demonstrated that superiority of potato-garlic ratios in comparison to unsprayed treatment. Among the proportions, high tuber yield and low disease incidence was found in garlic: potato (3:1) intercropped plots. Moreover, at 3:1 (garlic: potato) combination the land equivalent ratio (LER) was $>1$ and greater monetary values resulted. The study concluded that intercropping helps in managing potato against late blight.

\section{Black scurf}

Rhizoctonia solaniis a seed-borne or soilborne pathogen. The development of Rhizoctonia solani in potato occurs at low temperatures due to hampered emergence rate, high soil moisture as fungus grow at faster rate compared to plantlets and neutral to acid soil $(<\mathrm{pH} 7)$.

Symptoms: Pre-emerging sprouts die, cankers develop on the underground stem parts and stolons of the potato, potato progeny tubers provide shelter for sclerotia to develop constituting towards the key symptoms of black scurf.

Management: To occasionally escape black scurf the potato crop should be harvested early, after destructing haulm (Mulder et al., 1992). Combined green harvesting and hyperparasite Verticillium bigutatum use helps in controlling disease better (van den Boogert et al., 2005). Under greenhouse conditions, attack of pathogen $R$. solani was controlled via usage of Trichoderma harzianum (Schroth and Hancock, 1981). Combining $T$. harzianum with soil solarization decreased disease infection (Elad et al., 1980). R. Solani infection was decreased upon soil treatment with Laetisaria arvalis (Murdoch and Leach, 1993). Application of the organic matter not only progresses soil structure but also increases soil water holding capacity and promotes plant growth. Soil-borne plant pathogens attack is inhibited by the use of composts. $R$. solani propagation reduction occurred due to cattle manure application in the soil (Kuter et al., 1983), reason beingapproved antagonistic microorganisms for the biological control against various diseases, such as $T$. harzianum, Pseudomonas yuorescens, Enterobacter cloacae etc. (Kleifeld et al., 1996) activities were enhanced.

\section{Wart}

The fungus Synchytrium endoboiticum is responsible for causing wart disease of potato. This obligate parasite mostly develops in warm temperatures (up to $20{ }^{\circ} \mathrm{C}$ ) with more relative humidity. Sporangia remain active for many years and can survive up to $50 \mathrm{~cm}$ soil depth.

Symptoms: Tubers, flowers, leaves and stems, produce warty exudations, therefore, the disease is known as potato wart, (Hooker, 1981). Different sized, green or brown coloured gall formation are principle symptoms. Tubers distort in younger stages and hence, become spongy. However, unlike roots stolons in older tubers are infected and give warty appearance. The leaves become pulpy and soft in nature, if attacked. Morphologically, the hyperplastic tissue mass mixed along with the proliferated leaves and branches can be noticed. This pathogen reduces plant vigour but does not kill it.

Management: The European and Mediterranean Plant Protection Organization (EPPO) consider $S$. endoboiticum A2 quarantine pest resulting in the policing making to hamper pathogen spread across the globe. The European Union (EU) has enacted 
preferable requirements in Dec. $8^{\text {th }} 1969$ 's 'Council Directive 69/464/EEC for controlling Potato Wart Disease' and May $8^{\text {th }}$ 2000's 'Council Directive 2000/29/EC on protective measures to safeguard their community from disastrous pathogens (Obidiegwu et al., 2014) by various quarantine measures against infected products. 'EPPO specific quarantine requirements' mentions that in $S$. endoboiticum infected fields, the potato trials are not allowed. Also, ban on trade and seed production of diseased potato is imposed. If during field diagnoses $S$. endoboiticum prevails, potato production on that particular site or location is not allowed for 20 years followed by Union members. After that period soil tests have to be passed to initiate again. Council Directive 69/464/EEC says, that Union Members have the right to follow stricter rules as per their choice as chemical controls are ineffective till date to exudates sporangia from soil. Hampson (1977) discovered 120 chemicals, inorganic or organic, singly or in combination have not given significant results except few. Chemically treated soils became barren (De Boer 2005) and hence, none recommendation of chemical (Hampson, 1993) exist to control this. (Obidiegwu et al., 2014) tried to minimise wart effect from 97 to $25 \%$ using biological control solution along with potato slices culture with actinomycetes, diluting them in sand and including it in infested pot soil mixes. Simultaneous soil treatment proved better resulting in 3-year treatment program proposal to discard soil borne pathogen. The biological control Thiobacillus thiooxydans proposed by Roach et al., (1925) was significantly effective while repeated trials proved it to be insignificant to control potato wart. In addition, crop rotation and intercropping with maize effectively minimized S. endoboiticum population (Singh and Shekhawat, 2000).
Summary and conclusion of the study are as follows:

The important food crop of the world, potato (Solanum tuberosum) used in household and industrial purposes. The properties of potato are greatly affected by the attack of various pathogens leading to the economic and quality loss to everyone producers, processors and consumers. Therefore, the effective disease management is necessary. Although efforts via single management approaches are made with little affect but integrated management of fungal diseases is necessary to feed the future and sustainable agriculture.

\section{Acknowledgement}

I express my sincere and deepest Gratitude to the God Glory to Him. Secondly, I extend it to the Sikh Nation citizens for providing me environment to gain education in South Asian part of the World peacefully. I am also heartily thankful to the co-authors for encouraging and helping me to write this review.

\section{References}

Arora, R.K., Sharma, S. and Singh, B.P., 2014. Late blight disease of potato and its management. Potato Journal. 41(1).

Bodker, I., Pedersen, H., Kristensen. K., Moller, L., Lehtinen, A. and Hannukkala, A., 2005. Influence of crop history of potato on early occurrence and disease severity of potato late blight caused by Phythophthora infestans. Ninth workshop of and European network for development of an Integrated Control Strategy of potato late blight, Tallinn. Pp 19-23

Bødker, L., Pedersen, H., Kristensen, K., Møller, L., Lehtinen, A. and Hannukkala, A., 2006. Bofu, S., Yu, Q.D. and Vander Zaag, P., 1987. True 
potato seed in China: past, present and future.

Bounes, H. and Finckh, M. R., 2008 Effects of strip intercropping of potatoes with non-hosts on late blight severity and tuber yield in organic production. Plant Patho. 57: 916-27

Carnegie, S.F. and Colhoun, J., 1980. Differential leaf susceptibility to Phytophthora infestans on potato plants of cv. King Edward. Journal of Phytopathology. 98 (2): 108-117.

De Boer, S., 2005. Emerging potato disease challenges- an overview. Potato Reporter Online. Available online: http://www.potatoreportonlione.com

Douglas, D.R. and Groskopp, M.D., 1974. Control of early blight in eastern and south central Idaho. American Potato Journal. 51 (11): 361-368.

Elad, Y., Katan, J. and Chet, I., 1980. Physical, biological, and chemical control integrated for soil borne diseases in potatoes. Phytopathology. 70 (5): 418-422.

Ellis, J.B. and Martin, G.B. 1882 Macrosporium solani E \& M American Naturalist. 16: 10

Flier, W.G. and Turkensteen, L.J., 1999. Foliar aggressiveness of Phytophthorainfestans in three potatogrowing regions in the Netherlands. European Journal of Plant Pathology. 105 (4): 381-388.

Frenkel, O., Yermiyahu, U., Forbes, G.A., Fry, W.E. and Shtienberg, D., 2010. Restriction of potato and tomato late blight development by sub- phytotoxic concentrations of boron. Plant pathology. 59 (4): 626-633.

Garrett, K.A. and Mundt, C.C., 2000. Host diversity can reduce potato late blight severity for focal and general patterns of primary inoculum. Phytopathology. 90 (12): 1307-1312.

Gupta, H., Singh, B. P. and Mohan, J., 2004.
Biocontrol of late blight of potato. Potato J. 31: 39-42

Hampson, M.C. and Thompson, P.R., 1977. A quantitative method to examine large numbers of soil samples for Synchytrium endoboiticum, the cause of potato wart disease. Plant and Soil. 46 (3): 659-664.

Hampson, M.C., 1993. History, biology and control of potato wart disease in Canada. Canadian Journal of Plant Pathology. 15 (4): 223-244.

Hannukkala, A.O., Kaukoranta, T., Lehtinen, A. and Rahkonen, A., 2007. Late- blight epidemics on potato in Finland, 1933-2002; increased and earlier occurrence of epidemics associated with climate change and lack of rotation. Plant Pathology. 56 (1): 167-176.

Harrison, M.D. and Venette, J.R., 1970. Chemical control of potato early blight and its effect on potato yield. American Potato Journal. 47 (3): 81-86.

Hooker, W.J., 1981. Compendium of potato diseases. International Potato Center.

Jones, L.R., 1893. The new potato disease or early blight. Vermont Agricultural Experimental Station Bulletin. 6: 66-70.

Jones, L.R., 1912. Potato diseases in Wisconsin and their control. University of Wisconsin, Agricultural Experiment Station.

Kankoranta, T. 1996. Impact of globe warming on potato late blight: risk, yield loss and control. Agricultural and Food Science in Finland. 5: 311-327.

Kleifeld, O., Chet, I., Abramsky, M., Yedidia, I. and Agron, L., 1996. The use of Trichoderma 2000 for control of plant diseases. Phytoparasitica. 24: 148-149.

Kuter, G. A., Nelson, E. B. and Hoitink, H. A. J., 1983. Effects of fungal antagonists and compost age on suppression of Rhizoctonia damping off in container media amended with 
composted hardwood bark. Phytopathology 73: 1457-1462

Kuzuestova, M. A., Schcherbakova, L. A., Ihnskaya, L. I., Filippov, A. V. and Ozeretekovskay, 1995. Mycelium extract of the fungus Pythium ultimum is an efficient preventive of Phytophthora infection. Microbiology. 64: 422-24

Lowings, P.H. and Acha, I.G., 1959. Some factors affecting growth of Phytophtho rainfestans (mont.) de Bary: IP Infestans on living potato leaves. Transactions of the British Mycological Society. 42 (4): 491-501.

Madden, L., Pennypacker, S.P. and MacNab, A.A., 1978. FAST, a forecast system for Alternaria solani on tomato. Phytopathology. 68 (9): 1354-1358.

Mulder, A., Turkensteen, L.J. and Bouman, A., 1992. Perspectives of green-cropharvesting to control soil-borne and storage diseases of seed potatoes. Netherlands Journal of Plant Pathology. 98 (2): 103-114.

Murdoch, C.W. and Leach, S.S., 1993. Evaluation of Laetisaria arvalis as a biological control agent of Rhizoctonia solani on white potato. American Potato Journal. 70 (9): 625-634.

Niederhauser, J.S., Alvarez-Luna, E. and Mackenzie, D.R., 1996. RETONA a new strategy in the control of potato late blight. American Potato Journal. 73 (5): 225-229.

Obidiegwu, J.E., Flath, K. and Gebhardt, C., 2014. Managing potato wart: a review of present research status and future perspective. Theoretical and Applied Genetics. 127 (4): 763-780.

Rajputt, N.A., Khan, S.A. and Ahmad, A., 2017. Population structure of Phytophthora infestans on worldwide scale: a review. Pakistan Journal of Phytopathology. 29 (2): 281-288.

Rands, R.D., 1917. Early blight of potato and related plants (Vol. 42). Agricultural Experiment Station of the University of Wisconsin.

Roach, W.A., Glynne, M.D., Brierley, W.B. and Crowther, E.M., 1925. Experiments on the control of wart disease of potatoes by soil treatment with particular reference to the use of sulphur. Annals of Applied Biology. 12(2): 152-190.

Roy, S.K., Sharma, R.C. and Trehan, S.P., 2001. Integrated nutrient management by using farmyard manure and fertilizers in potato-sunflower-paddy rice rotation in the Punjab. The Journal of Agricultural Science. 137 (3): 271278.

Schroth, M.N. and Hancock, J.G., 1985. Soil antagonists in IPM systems.

Shtienberg, D. and Fry, W.E., 1990. Influence of host resistance and crop rotation on initial appearance of potato early blight. Plant disease 74 (11): 849852.

Singh, P.H. and Shekhawat, G.S., 2000. Wart disease of potato in Darjeeling hills. Technical Bulletin. (19) 73.

Teng, P.S. and Bissonnette, H.L., 1985. Potato yield losses due to early blight in Minnesota fields, 1981 and 1982. American Potato Journal. 62 (11): 619627.

Tiwari, J.K., Siddappa, S., Singh, B.P., Kaushik, S.K., Chakrabarti, S.K., Bhardwaj, V. and Chandel, P., 2013. Molecular markers for late blight resistance breeding of potato: an update. Plant Breeding. 132 (3):237-245.

Tsai, J., Ann, P., Wang, L., Wang, S. and Hu, C., 2009. Control of Phytophthora late blight of potato and tomato with neutralized phosphorous acid. J Taiwan Agric Res. 58: 185-95

Van den Boogert, P.H.J.F., van Gent-Pelzer, M.P.E., Bonants, P.J.M., De Boer, S.H., Wander, J.G.N., Lévesque, C.A., Van 
Leeuwen, G.C.M. and Baayen, R.P., 2005. Development of PCR-based detection methods for the quarantine phytopathogen Synchytrium endoboiticum, causal agent of potato wart disease. European Journal of Plant Pathology. 113 (1): 47-57.

Van der Waals, J.E., Korsten, L. and Aveling, T.A.S., 2001. A review of early blight of potato. African Plant Protection. 7 (2): 91-102.

Vowinckel, O, $1925 . \quad$ Die AnfälligkeitdeutscherKartoffelsortengeg enüber Phytophthora infestansMont. de by. Unterbesonderer Berücksichtigung der Untersuchungensmethoden (Doctoral dissertation, Müllers).

Woodham-Smith, C. 1991. The great hunger: Ireland, 1845-9. London: Penguin.

Zwankhuizen, M.J., Govers, F. and Zadoks, J.C., 2000. Inoculum sources and genotypic diversity of Phytophthora infestans in Southern Flevoland, the Netherlands. European Journal of Plant Pathology. 106 (7): 667-680.

\section{How to cite this article:}

Arshdeep Singh and Jagjeewan Singh. 2018. Integrated Management of Fungal Diseases in Potato. Int.J.Curr.Microbiol.App.Sci. 7(08): 4443-4450.

doi: https://doi.org/10.20546/ijcmas.2018.708.469 